\title{
Inhibitory effects of nitric oxide on estrogen production and cAMP levels in rat granulosa cell cultures
}

\author{
R S Ishimaru, K Leung, L-S Hong and P S LaPolt \\ Department of Biology and Microbiology, California State University, Los Angeles, California 90032, USA \\ (Requests for offprints should be addressed to P S LaPolt, Department of Biology and Microbiology, 5151 State University Drive, California State University, \\ Los Angeles, California 90032, USA; Email: plapolt@calstatela.edu)
}

\begin{abstract}
Previous studies demonstrated inhibitory effects of nitric oxide (NO) and cGMP on ovarian steroidogenesis. This study examined the effects of $\mathrm{NO}$ on estrogen levels and cAMP accumulation from immature cultured rat granulosa cells. Granulosa cells were incubated with media alone (control), FSH or FSH plus increasing concentrations of the NO generator, (Z)-1-[2-(2-aminoethyl)-N-(2ammonioethyl)amino]diazen-1-ium-1,2-diolate (DETA/ NO). While FSH increased estrogen levels 15-fold compared with controls, DETA/NO inhibited FSHstimulated aromatase activity in a dose-dependent manner. Time-course studies revealed that the inhibitory effects of DETA/NO on aromatase activity persisted throughout the $72 \mathrm{~h}$ culture period. Treatment with DETA/NO also inhibited the stimulatory effects of forskolin on estrogen
\end{abstract}

production, indicating that $\mathrm{NO}$ can influence steroidogenesis by actions downstream of the $\mathrm{FSH}$ receptor. Incubation of cells with FSH plus DETA/NO increased cGMP accumulation over 100-fold, compared with cells treated with media or FSH alone. In this regard, a cGMP analog mimicked the inhibitory effects of $\mathrm{NO}$ on FSHand forskolin-stimulated estrogen production, indicating a potential mechanism of $\mathrm{NO}$ action. $\mathrm{NO}$ also decreased FSH-stimulated (cAMP) accumulation from cultured cells, indicating an antagonistic effect of $\mathrm{NO}$ on the second messenger mediating FSH actions. These findings demonstrate that NO inhibits estrogen production from rat granulosa cells, potentially reflecting actions on the second messengers cGMP and cAMP.

Journal of Endocrinology (2001) 168, 249-255

\section{Introduction}

Estradiol (E2) plays essential roles in the establishment and maintenance of the female reproductive system. Ovarian E2 production is dependent upon the induction of the enzyme cytochrome P450 aromatase, which catalyzes the conversion of androgens to estrogens. The induction of aromatase mRNA and protein in ovarian granulosa cells is dependent upon exposure to follicle-stimulating hormone (FSH), which acts through its $\mathrm{G}$ protein-coupled receptor to activate adenylyl cyclase and stimulate production of the second messenger cAMP (Erickson \& Hsueh 1978, Hsueh et al. 1984, Hickey et al. 1988). In addition to the stimulatory effects of $\mathrm{FSH}$, the induction of aromatase activity in granulosa cells is modulated by a number of other hormones, growth factors and peptides (Hsueh et al. 1984, Adashi \& Resnick 1986, Mendelson et al. 1986, Krasnow et al. 1990, LaPolt \& Hong 1995).

Nitric oxide (NO) is a diffusible gas which has been implicated as a signaling molecule in a variety of cellular functions, including vasodilation, neurotransmission and macrophage toxicity (Moncada et al. 1991). Previous studies suggest that NO may play important roles in the ovary, influencing processes such as ovulation, follicular development, oocyte maturation, apoptosis and steroidogenesis (Shukovski \& Tsafriri 1994, Chun et al. 1995, Snyder et al. 1996, Masuda et al. 1997, Yamauchi et al. 1997, Matsumi et al. 1998b, Jablonka-Shariff et al. 1999a). Two forms of NO synthase (NOS), the enzyme catalyzing NO production, are expressed in the ovary in a regulated manner (Van Voohris et al. 1995, Jablonka-Sharriff \& Olson 1997, Matsumi et al. 1998b). Although the literature is not in complete agreement, it appears that the main form of NOS expressed in granulosa cells of small follicles is inducible NOS (iNOS), the expression of which apparently decreases during follicular growth (Van Voorhis et al. 1995). In addition, iNOS is expressed primarily in follicles that are functionally immature, rather than developed follicles (Matsumi et al. 1998b). In contrast, endothelial NOS (eNOS) is expressed in ovarian thecal and stromal cells, in mural granulosa cells of maturing follicles, and in corpora lutea (Jablonka-Sharriff \& Olson 1997). The regulated expression of NOS isoforms in the ovary is consistent with a physiological role of $\mathrm{NO}$ in ovarian functions. In addition, factors known to modulate granulosa cell function, such as interleukin-1, may exert their influences at least in part through induction of $\mathrm{NO}$ (Ben-Shlomo et al. 1994). 
The actions of $\mathrm{NO}$ are mediated by activation of soluble guanylyl cyclase, resulting in increased cGMP production (Ignarro 1990). However, NO also influences enzyme activity by interactions between $\mathrm{NO}$ and heme or sulfhydryl moieties on proteins (Stamler 1994). In this regard, previous studies indicate that NO directly inhibits the activity of enzymes such as cytochrome P450 side chain cleavage and aromatase (Snyder et al. 1996, Hanke et al. 1998), as well as two isoforms of adenylyl cyclase (Duhe et al. 1994, McVey et al. 1999). While NO has been reported to inhibit estrogen production in both human granulosa-luteal cells and porcine granulosa cells in a cGMP-independent manner (Snyder et al. 1996, Masuda et al. 1997), our previous findings demonstrate an inhibitory effect of cGMP on FSH-stimulated E2 production in rat granulosa cells (LaPolt \& Hong 1995), suggesting an additional mechanism of $\mathrm{NO}$ action. Furthermore, some actions of cGMP and $\mathrm{NO}$ are known to reflect modulation of adenylyl cyclase and phosphodiesterase activity, resulting in decreased cAMP production and accumulation (Macfarland et al. 1991, McVey et al. 1999). Therefore, it is conceivable that NO and cGMP may exert significant influences on the levels of cAMP, the second messenger mediating FSH actions. The present studies examined further the effects of NO and cGMP on steroidogenesis and second messenger signaling in cultured rat granulosa cells.

\section{Materials and Methods}

\section{Hormones and reagents}

Ovine FSH (oFSH-19-SIAFP; $94 \times$ NIH-oFSH-S1) was obtained from the National Hormone and Pituitary Program, National Institute of Diabetes, Digestive and Kidney Diseases (NIDDK), National Institutes of Health (NIH), Bethesda, MD, USA. Forskolin (FSK) and dibutyryl cGMP $\left((\mathrm{Bu})_{2} \mathrm{cGMP}\right)$ were purchased from Sigma Chemical Co. (St Louis, MO, USA). The NO generator (Z) -1-[2-(2-aminoethyl)-N-(2-ammonioethyl)amino] diazen-1-ium-1,2-diolate (DETA/NO) was obtained from Alexis Corporation (San Diego, CA, USA). McCoy's 5A medium (modified, serum-free), trypan blue, streptomycin sulfate, penicillin and L-glutamine were obtained from Life Technologies (Rockville, MD, USA). The levels of cGMP and cAMP were measured using commercial RIA kits (Amersham Corp., Arlington Heights, IL, USA). All other chemicals were reagent grade obtained from Fisher Scientific (Pittsburgh, PA, USA).

\section{Granulosa cell culture}

Granulosa cells were obtained from immature, estrogentreated Sprague-Dawley female rats (Harlan Sprague Dawley, Indianapolis, IN, USA) as previously described
(LaPolt \& Hong 1995). Cells were cultured in $12 \times 75 \mathrm{~mm}$ polypropylene culture tubes (Falcon Plastics, Oxnard, CA, USA) at a concentration of 125000 viable cells $/ 0.5 \mathrm{ml}$ McCoy's $5 \mathrm{~A}$ medium supplemented with antibiotics and $10^{-7} \mathrm{M}$ androstenedione, with or without added hormones and reagents. Cell viability was assessed using trypan blue exclusion staining. Incubations were performed at $37{ }^{\circ} \mathrm{C}$ in a humidified $5 \% \mathrm{CO}_{2}-95 \%$ air atmosphere for up to $72 \mathrm{~h}$. After incubation, medium was collected and stored at $-70{ }^{\circ} \mathrm{C}$ until assayed for E2 content, as an indication of aromatase activity. For cAMP and cGMP RIAs, cells and media were heated for $10 \mathrm{~min}$ at $90{ }^{\circ} \mathrm{C}$ to inactivate phosphodiesterases, and then frozen in a dry ice/methanol bath and stored at $-70{ }^{\circ} \mathrm{C}$ until assay.

\section{Estrogen RIA and data analysis}

The estrogen concentrations in conditioned granulosa cell medium were determined by RIA, as previously reported (LaPolt \& Hong 1995). Each cell culture experiment was analyzed within the same assay. Experiments were performed in triplicate, and each experiment was repeated at least three times. Differences between treatment groups were determined by one-way or two-way ANOVA, and a confidence level of $P<0.05$ was considered statistically significant.

\section{Results}

Effects of DETA/NO on FSH-induced estrogen production by cultured rat granulosa cells

Treatment of granulosa cells with FSH $(1 \mathrm{ng} / \mathrm{ml})$ markedly increased estrogen levels compared with cells treated with culture medium alone (control; Fig. 1). To examine the effects of $\mathrm{NO}$ on granulosa cell function, we utilized the NO generator DETA/NO, which has a long halflife of NO release (Shimaoka et al. 1995). Treatment of granulosa cells with FSH plus increasing doses of DETA/NO $(30-250 \mu \mathrm{M})$ resulted in decreasing levels of estrogen production (Fig. 1), indicating that $\mathrm{NO}$ inhibits FSH-induced aromatase activity in a dosedependent manner.

\section{Time-course of FSH and DETA/NO actions on E2 production in rat granulosa cells}

To determine the time-course during which NO inhibits FSH-induced estrogen production, cells were cultured with media alone (control), FSH $(1 \mathrm{ng} / \mathrm{ml})$ or FSH plus DETA/NO $(120 \mu \mathrm{M})$ (Fig. 2). Estrogen levels in the conditioned media were measured at $0,12,24,36,48$ or $72 \mathrm{~h}$ of culture. Untreated cells (control) produced low amounts of estrogen throughout $72 \mathrm{~h}$ of culture. In contrast, cells treated with FSH alone showed elevated levels 


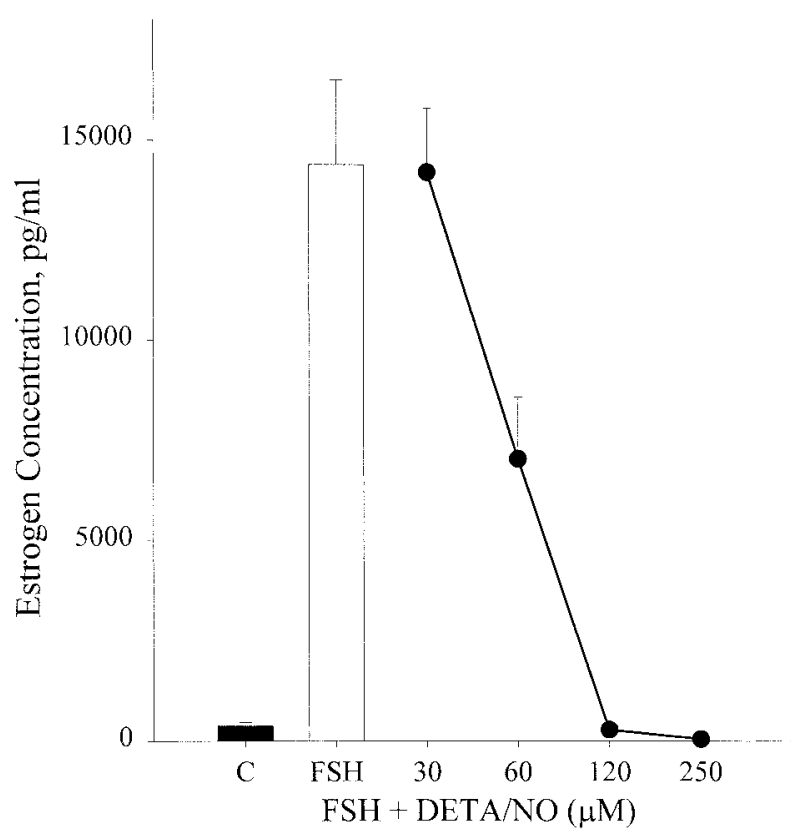

Figure 1 Dose-dependent effects of $\mathrm{NO}$ on FSH-stimulated estrogen production from rat granulosa cells. Cells were treated for $72 \mathrm{~h}$ with media alone (C; control), FSH (1 ng/ml) or FSH plus increasing concentrations of the $\mathrm{NO}$ generator, DETA/NO $(30-250 \mu \mathrm{M})$. After culture, media were collected to determine estrogen concentrations by E2 RIA.

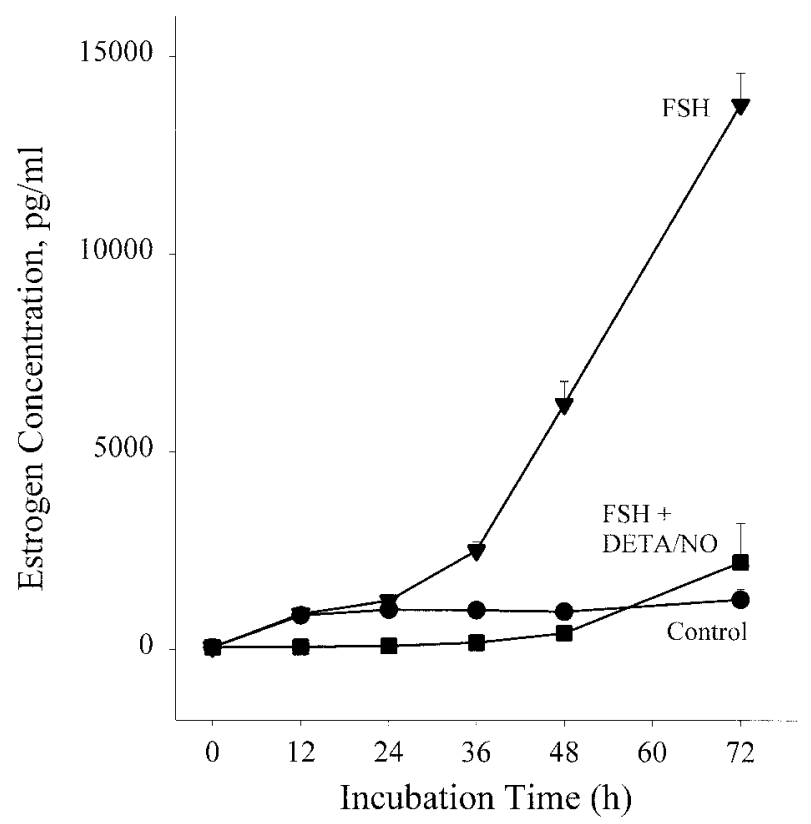

Figure 2 Time-course for inhibition of estrogen production by NO. Cells were treated with media alone (control), FSH $(1 \mathrm{ng} / \mathrm{ml})$ or FSH plus DETA/NO $(120 \mu \mathrm{M})$ for $12,24,36,48,60$ or $72 \mathrm{~h}$, followed by assay of media to determine estrogen concentrations.

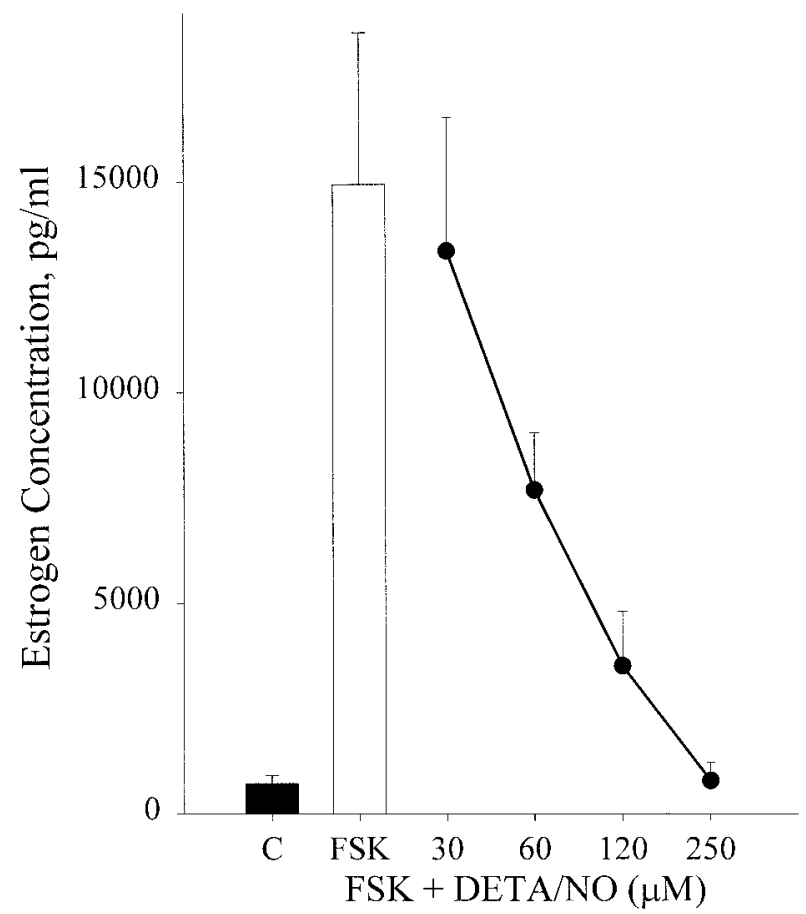

Figure 3 Dose-dependent effects of NO on FSK-stimulated estrogen production from rat granulosa cells. Cells were treated for $72 \mathrm{~h}$ with media alone $\left(\mathrm{C}\right.$; control), FSK $\left(10^{-4} \mathrm{M}\right)$ or FSK plus increasing concentrations $(30-250 \mu \mathrm{M})$ of the NO generator, DETA/NO.

of estrogen production beginning at $36 \mathrm{~h}$ of incubation, with the greatest accumulation occurring at $72 \mathrm{~h}$. Cotreatment of cells with FSH plus DETA/NO completely prevented any increase in estrogen production throughout the entire culture period. These results indicate that while FSH stimulates estrogen production in a time-dependent manner, NO exerts a continuous suppression of FSHinduced aromatase activity.

Effects of DETA/NO on FSK-induced estrogen production by cultured rat granulosa cells

The inhibitory effects of $\mathrm{NO}$ on FSH-induced aromatase activity may reflect influences of $\mathrm{NO}$ on the FSH receptor (receptor expression, ligand binding and/or signal transduction) and/or on post-receptor events required for cAMP production and signaling. To determine whether NO might act at a post-FSH receptor site we directly stimulated cAMP production with the adenylyl cyclase activator FSK, bypassing the FSH receptor and associated guanine nucleotide-binding protein. As anticipated, treatment of cells with FSK alone $\left(10^{-4} \mathrm{M}\right)$ markedly elevated estrogen levels in comparison with untreated control cells (Fig. 3). In contrast, cotreatment of cells with FSK and increasing doses of DETA/NO $(30-250 \mu \mathrm{M})$ progressively inhibited estrogen production, indicating that $\mathrm{NO}$ 


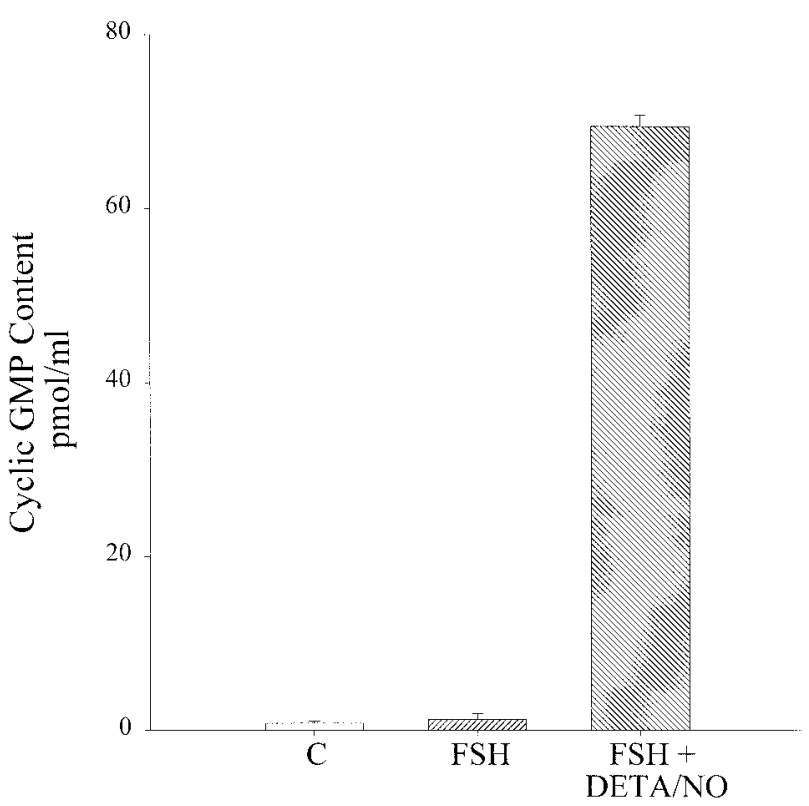

Figure 4 Influence of FSH and DETA/NO on cGMP accumulation from cultures of rat granulosa cells. To determine the relationship between the induction of aromatase activity and cGMP levels, cells were treated for $72 \mathrm{~h}$ with media alone (C; control), $\mathrm{FSH}$ $(1 \mathrm{ng} / \mathrm{ml})$ or FSH plus DETA/NO $(120 \mu \mathrm{M})$.

can inhibit estrogen production from rat granulosa cells at one or more post-FSH receptor sites.

\section{Effects of NO on cGMP accumulation of cultured rat} granulosa cells

Since NO mediates many of its effects through cGMPdependent signaling pathways by activating soluble guanylyl cyclase, we next established whether NO could stimulate cGMP levels in rat granulosa cell cultures. Cells treated with media alone or with FSH $(1 \cdot 0 \mathrm{ng} / \mathrm{ml})$ exhibited low levels of cGMP accumulation in cells and media after $72 \mathrm{~h}$ of culture. In contrast, cultures cotreated with FSH plus DETA/NO $(120 \mu \mathrm{M})$ displayed an over 100fold increase in cGMP accumulation, compared with control cells (Fig. 4). These data demonstrate that DETA/NO effectively stimulates cGMP accumulation in cultured rat granulosa cells, and is consistent with the stimulatory effects of $\mathrm{NO}$ on guanylyl cyclase activation. Furthermore, these findings suggest a potential role of cGMP as a second messenger mediating the actions of $\mathrm{NO}$ on ovarian steroidogenesis.

\section{Influence of a CGMP analog on FSH- and FSK-induced aromatase activity}

Previous studies have reported that exogenous cGMP does not have a significant effect on steroidogenesis in human granulosa-luteal cells (Van Voorhis et al. 1994) and in

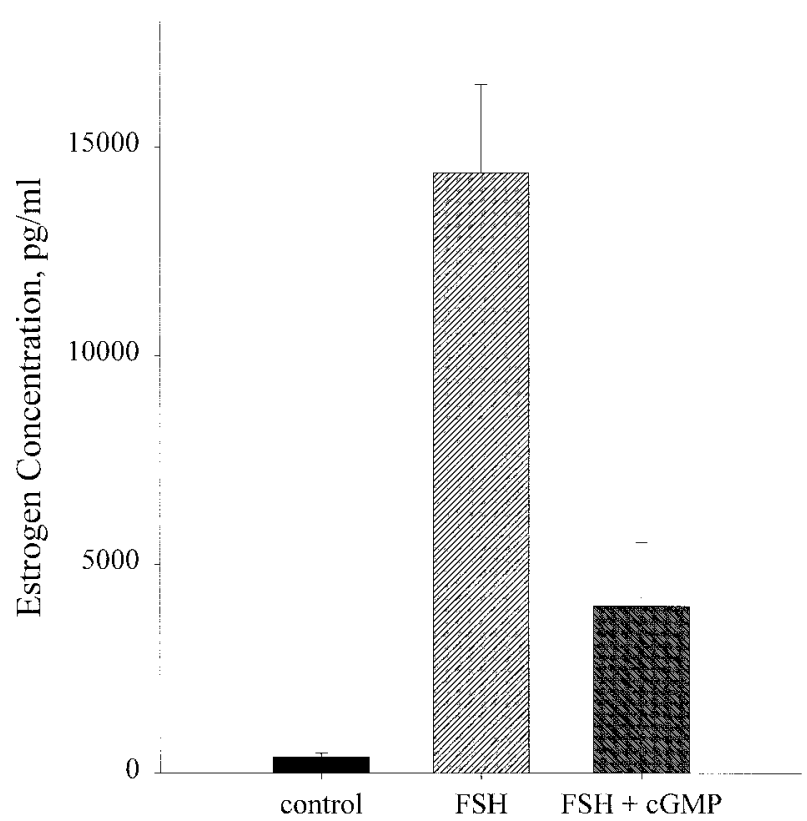

Figure 5 Effects of $(\mathrm{Bu})_{2} \mathrm{CGMP}$ on FSH-stimulated estrogen production from rat granulosa cells. Cells were treated for $72 \mathrm{~h}$ with media alone (control), FSH $(1 \mathrm{ng} / \mathrm{ml})$ or FSH plus $(\mathrm{Bu})_{2} \mathrm{CGMP}$ $(2 \mathrm{mM})$, followed by measurement of estrogen concentrations by RIA.

porcine granulosa cells (Masuda et al. 1997). However, we have previously found that the cGMP analog $(\mathrm{Bu})_{2} \mathrm{cGMP}$ inhibits aromatase activity in rat granulosa cells (LaPolt \& Hong 1995). To further confirm the effects of cGMP on FSH-induced aromatase activity, granulosa cells were cultured with FSH and $(\mathrm{Bu})_{2}$ cGMP. As shown above, treatment of cells with FSH alone $(1 \cdot 0 \mathrm{ng} / \mathrm{ml})$ markedly stimulated estrogen production, compared with controls. In contrast, estrogen production from cells cotreated with FSH plus $(\mathrm{Bu})_{2} \mathrm{cGMP}(2 \mathrm{mM})$ was significantly reduced, compared with that in cells incubated with FSH alone (Fig. 5). Similarly, while FSK $\left(10^{-4} \mathrm{M}\right)$ markedly increased estrogen concentrations compared with control cells, cotreatment with FSK plus $(\mathrm{Bu})_{2} \mathrm{cGMP}(2 \mathrm{mM})$ inhibited estrogen levels compared with cells cultured with FSK alone (Fig. 6). Higher levels of $(\mathrm{Bu})_{2} \mathrm{cGMP}$ $(4 \mathrm{mM})$ did not further inhibit FSH- or FSK-stimulated E2 levels (data not shown).

Effects of FSH and NO on cAMP accumulation in cultured rat granulosa cells

To address whether NO might inhibit estrogen production by decreasing FSH-induced cAMP levels, cells were incubated for $72 \mathrm{~h}$ with medium alone (control), FSH $(1.0 \mathrm{ng} / \mathrm{ml})$ or $\mathrm{FSH}$ plus a maximally inhibiting dose of DETA/NO $(120 \mu \mathrm{M})$, and accumulated levels of cAMP in the cells and media were determined by RIA. As 


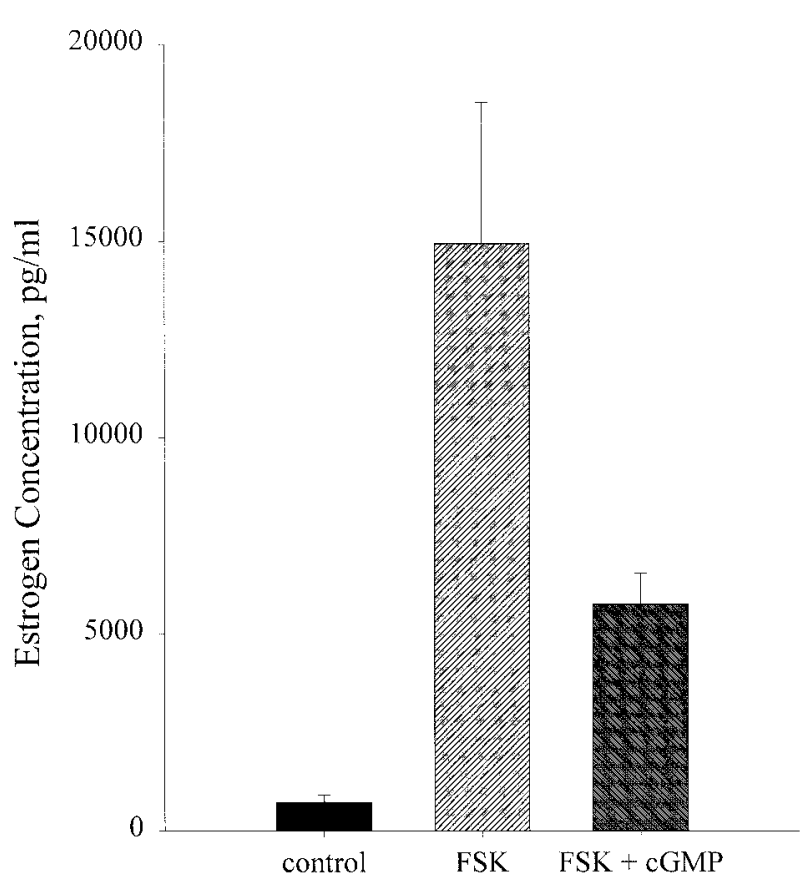

Figure 6 Influence of $(\mathrm{Bu})_{2} \mathrm{CGMP}$ on FSK-stimulated estrogen production from rat granulosa cells. Cells were treated for $72 \mathrm{~h}$ with media alone (control), FSK $\left(10^{-4} \mathrm{M}\right)$ or FSK plus $(\mathrm{Bu})_{2} \mathrm{cGMP}$ (2 mM).

expected, cAMP levels were very low in control cells. In contrast, treatment of cells with FSH markedly increased cAMP accumulation, as anticipated (Fig. 7). Cotreatment of cells with FSH and DETA/NO, however, significantly decreased cAMP levels compared with those seen from cells treated with FSH alone. These findings are consistent with the hypothesis that NO inhibits FSH-stimulated estrogen production in part by decreasing levels of the second messenger mediating FSH action.

\section{Discussion}

During follicular development, FSH acts through the cAMP-dependent protein kinase A pathway to induce aromatase activity in granulosa cells. However, the stimulatory effect of FSH on estrogen production is influenced by other hormones, growth factors and gonadal peptides, indicating the presence of diverse mechanisms regulating ovarian steroidogenesis. Results of the present study contribute further evidence that $\mathrm{NO}$ is a modulatory factor that effectively inhibits FSH- and cAMP-dependent estrogen production. Using cultures of rat granulosa cells, we have demonstrated that the NO generator, DETA/NO, inhibits FSH-induced aromatase activity in a dosedependent manner at one or more post-FSH receptor sites. Furthermore, our data indicate that the effects of NO may be mediated, at least in part, through increased levels of the

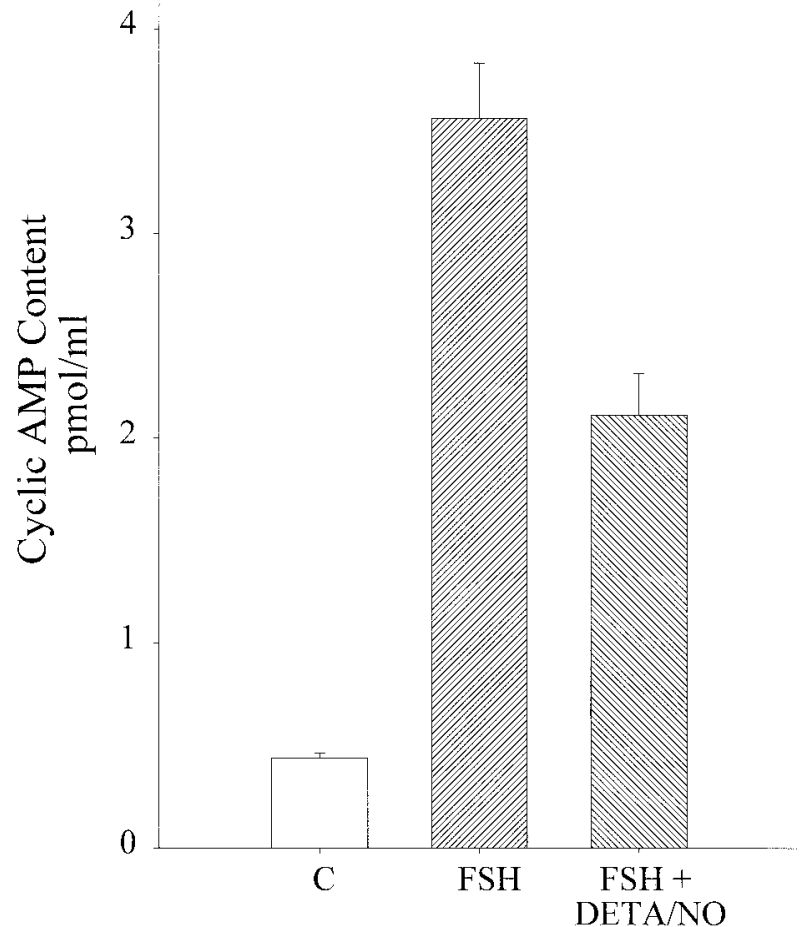

Figure 7 Inhibition of FSH-stimulated cAMP levels by DETA/NO. Granulosa cells were treated for $72 \mathrm{~h}$ with media alone (C; control), FSH $(1 \mathrm{ng} / \mathrm{ml})$ or FSH plus DETA/NO $(120 \mu \mathrm{M})$, followed by measurement of CAMP accumulation.

second messenger cGMP, and by attenuating FSHinduced cAMP levels. Overall, the data presented in this study add to the body of evidence indicating that $\mathrm{NO}$ and cGMP act as modulators of ovarian functions.

It is unlikely that the inhibitory effects of $\mathrm{NO}$ and cGMP on granulosa cell functions are due to deleterious effects of these factors on cell viability. Previous studies have indicated an inverse relationship between NO expression and apoptosis in granulosa cells (Matsumi et al. 1998a), and that treatment with NO donors prevents apoptosis in ovarian cells (Chun et al. 1995, Basini et al. 1998). Similarly, treatment of ovarian follicles with cGMP analogs prevents programmed cell death (Chun et al. 1995, McGee et al. 1997). In addition, NO does not appear to influence granulosa cell proliferation in culture (Basini et al. 1998). Thus, the observed effects on NO and cGMP on granulosa cell functions is believed to be independent of influences on cell number.

The site of action of $\mathrm{NO}$ and the detailed mechanisms by which $\mathrm{NO}$ inhibits ovarian steroidogenesis are not completely understood. We have demonstrated that NO inhibits FSK-induced aromatase activity in addition to FSH-induced steroidogenesis, indicating that $\mathrm{NO}$ can act distally to receptor activation. However, this result does 
not rule out additional effects of $\mathrm{NO}$ on the FSH receptor or its associated $\mathrm{G}$ protein. Previous studies have demonstrated that NO donors can inhibit FSH-induced E2 production in human granulosa-luteal cells and porcine granulosa cells (Snyder et al. 1996, Masuda et al. 1997, Kagabu et al. 1999). Snyder et al. (1996) proposed that NO directly inhibits aromatase activity by binding to a sulfhydryl group near the active site of the enzyme.

In addition to these potential direct effects on steroidogenic enzyme activity, the inhibitory effects of NO may also result from other signaling mechanisms. Snyder et al. (1996) also observed a significant inhibitory effect of NO on aromatase mRNA levels, indicating actions not limited to those directly affecting enzyme activity. Our results indicate that DETA/NO markedly increases levels of the second messenger cGMP in FSH-treated granulosa cell cultures. While others have reported that cGMP analogs have no effect on aromatase activity in luteinized human (Van Voohris et al. 1994) and 'moderately mature' porcine granulosa cells (Masuda et al. 1997), our previous (LaPolt \& Hong 1995) and present findings clearly demonstrate that treatment of immature rat granulosa cells with a cGMP analog effectively inhibits FSH- and FSK-induced estrogen levels in a dose-dependent manner. This discrepancy may reflect differences in the maturational state of granulosa cells used, as we used functionally immature cells as compared with the more mature granulosa cells used by the other investigators. This may suggest that cGMP acts by blocking the early initial events leading to granulosa cell maturation. In addition, studies in which no effect of cGMP on E2 production was found used shorter incubation times (16-24 h) and serum-based cell culture (compared with our use of serum-free conditions for $72 \mathrm{~h}$ ), as well as different species. It is clear from our observations that NO may inhibit the induction of estrogen production by a cGMP-dependent mechanism, in addition to having potential direct effects on aromatase activity.

The inhibitory effect of $\mathrm{NO}$ on FSH-induced aromatase activity is associated with an inhibition of FSH-stimulated cAMP levels from granulosa cell cultures. A dose of DETA/NO that maximally inhibited FSH-stimulated E2 production resulted in a $43 \%$ reduction in cAMP. This inhibitory effect of $\mathrm{NO}$ on cAMP accumulation is consistent with the recent observation that NO inhibits cAMP levels in cultured human granulosa-luteal cells (Kagabu et al. 1999). The mechanism through which NO inhibits cAMP levels in granulosa cells is not clear. Previous reports demonstrate direct inhibitory effects of $\mathrm{NO}$ on two isoforms of adenylyl cyclase (Duhe et al. 1994, McVey et al. 1999). Thus, NO may antagonize FSH-induced cAMP production by direct interactions with adenylyl cyclase. On the other hand, it is known that cGMP induces activity of a cGMP-stimulated phosphodiesterase (PDE2) that increases hydrolysis of cAMP (Rosman et al. 1997). For example, the inhibitory effect of atrial natriuretic peptide on adrenal aldosterone production and
cAMP levels is related to the induction of PDE2 (MacFarland et al. 1991). While it is not presently known whether PDE2 is expressed in the ovary, it is conceivable that the high levels of cGMP induced by treatment with DETA/NO inhibit cAMP levels by increasing PDE2 activity in granulosa cells. Clearly, further studies are required to elucidate the diverse molecular and biochemical mechanisms mediating the inhibitory effects of $\mathrm{NO}$ and cGMP on steroidogenesis of granulosa cells.

The physiological relevance of these in vitro studies is suggested by the pattern of NOS expression in the ovary, and by findings utilizing mice lacking NOS expression. One isoform of NOS (iNOS) is expressed primarily in follicles that are functionally immature (Matsumi et al. 1998b), and iNOS expression decreases during follicular growth (Van Voorhis et al. 1995). This may suggest that the acquisition of steroidogenesis in mature follicles is associated with decreased production of NO. On the other hand, while transgenic mice with a knockout of the iNOS gene display relatively normal patterns of cyclicity and steroidogenesis, knockout of the eNOS gene results in higher E2 levels on proestrus, consistent with an inhibitory effect of NO on aromatase activity (Jablonka-Shariff et al. 1999b). In this regard, eNOS expression increases in mural granulosa cells during follicular development (JablonkaShariff \& Olson 1997), indicating an inhibitory tone on estrogen production by granulosa cells. Together, these studies indicate that NO and cGMP play significant roles in the modulation of ovarian functions.

\section{Acknowledgements}

The authors thank the National Hormone and Pituitary Program, NIDDK, NIH, for the generous gift of oFSH. We also thank Junko Masutani for expert technical assistance.

Financial support for this research was provided by NIH Grant SO6 GM 8101, to P S L.

\section{References}

Adashi EY \& Resnick CE 1986 Antagonistic interactions of transforming growth factors in the regulation of granulosa cell differentiation. Endocrinology 119 1879-1881.

Basini G, Baratta M, Ponderato N, Bussolati S \& Tamanini C 1998 Is nitric oxide an autocrine modulator of bovine granulosa cell function? Reproduction, Fertility, and Development 10 471-478.

Ben-Shlomo I, Kokia E, Jackson MJ, Adashi EY \& Payne DW 1994 Interleukin-1 $\beta$ stimulates nitrite production in the rat ovary: evidence for heterologous cell-cell interaction and for insulinmediated regulation of the inducible isoform of nitric oxide synthase. Biology of Reproduction 51 310-318.

Chun SY, Eisenhower KM, Kubo M \& Hsueh AJW 1995 Interleukin-1 beta suppresses apoptosis in rat ovarian follicles by increasing nitric oxide production. Endocrinology 136 3120-3127.

Duhe RJ, Nielsen MD, Dittman AH, Villacres EC, Choi EJ \& Storm DR 1994 Oxidation of critical cysteine residues of type I adenylyl 
cyclase by $o$-iodosobenzoate or nitric oxide reversibly inhibits stimulation by calcium and calmodulin. Journal of Biological Chemistry 269 7290-7296.

Erickson GF \& Hsueh AJW 1978 Stimulation of aromatase activity by follicle-stimulating hormone in rat granulosa cells in vivo and in vitro. Endocrinology 102 1275-1282.

Hanke CJ, Drewett JG, Myers CR \& Campbell WB 1998 Nitric oxide inhibits aldosterone synthesis by a guanylyl cyclaseindependent effect. Endocrinology 139 4053-4060.

Hickey GJ, Chen S, Besman MJ, Shively JE, Hall PF, Gaddy-Kurten D \& Richards JS 1988 Hormonal regulation, tissue distribution and content of aromatase cytochrome P450 messenger ribonucleic acid and enzyme in rat ovarian follicles and corpora lutea: relationship to estradiol synthesis. Endocrinology 122 1426-1436.

Hsueh AJW, Adashi EY, Jones PBC \& Welsh TH Jr 1984 Hormonal regulation of the differentiation of cultured ovarian granulosa cells. Endocrine Reviews 5 76-127.

Ignarro LJ 1990 Biosynthesis and metabolism of endothelium-derived nitric oxide. Annual Review of Pharmacology and Toxicology 30 535-560.

Jablonka-Shariff A \& Olson LM 1997 Hormonal regulation of nitric oxide synthases and their cell-specific expression during follicular development in the rat ovary. Endocrinology 138 460-468.

Jablonka-Shariff A, Basuray R \& Olson LM 1999a Inhibitors of nitric oxide synthase influence oocyte maturation in rats. Journal of the Society for Gynecologic Investigation 6 95-101.

Jablonka-Shariff A, Ravi S, Beltsos AN, Murphy LL \& Olson LM $1999 b$ Abnormal estrous cyclicity after disruption of endothelial and inducible nitric oxide synthase in mice. Biology of Reproduction $\mathbf{6 1}$ 171-177.

Kagabu S, Kodama H, Fukuda J, Karube A, Murata M \& Tanaka T 1999 Inhibitory effects of nitric oxide on the expression and activity of aromatase in human granulosa cells. Molecular Human Reproduction 5 396-401.

Krasnow JS, Hickey GJ \& Richards JS 1990 Regulation of aromatase mRNA and estradiol biosynthesis in rat ovarian granulosa and luteal cells by prolactin. Molecular Endocrinology 4 13-21.

LaPolt PS \& Hong LS 1995 Inhibitory effects of superoxide dismutase and cyclic guanosine $3^{\prime}, 5^{\prime}$-monophosphate on estrogen production in cultured rat granulosa cells. Endocrinology 136 5533-5539.

Macfarland RT, Zelus BD \& Beavo JA 1991 High concentrations of a cGMP-stimulated phosphodiesterase mediate ANP-induced decreases in cAMP and steroidogenesis in adrenal glomerulosa cells. Journal of Biological Chemistry 266 136-142.

McGee E, Spears N, Minami S, Hsu SY, Chun SY, Billig H \& Hsueh AJ 1997 Preantral ovarian follicles in serum-free culture: suppression of apoptosis after activation of the cyclic guanosine $3^{\prime}, 5^{\prime}$-monophosphate pathway and stimulation of growth and differentiation by follicle-stimulating hormone. Endocrinology 138 2417-2424

McVey M, Hill J, Howlett A \& Klein C 1999 Adenylyl cyclase, a coincidence detector for nitric oxide. Journal of Biological Chemistry 274 18887-18892.
Masuda M, Kubota T, Kamada S \& Aso T 1997 Nitric oxide inhibits steroidogenesis in cultured porcine granulosa cells. Molecular Human Reproduction 3 285-292.

Matsumi H, Koji T, Yano T, Yano N, Tsutsumi O, Momoeda M, Osuga Y \& Taketani Y 1998a Evidence for an inverse relationship between apoptosis and inducible nitric oxide synthase expression in rat granulosa cells: a possible role of nitric oxide in ovarian follicle atresia. Endocrine Journal 45 745-751.

Matsumi H, Yano T, Koji T, Ogura T, Tsutsumi O, Taketani Y \& Esumi H $1998 b$ Expression and localization of inducible nitric oxide synthase in the rat ovary: a possible involvement of nitric oxide in the follicular development. Biochemical and Biophysical Research Communications 243 67-72.

Mendelson CR, Corbin CJ, Smith ME, Smith J \& Simpson ER 1986 Growth factors suppress and phorbol esters potentiate the action of dibutyryl adenosine $3^{\prime}, 5^{\prime}$-monophosphate to stimulate aromatase activity of human adipose stromal cells. Endocrinology 118 968-973.

Moncada S, Palmer RM \& Higgs EA 1991 Nitric oxide: physiology, pathophysiology, and pharmacology. Pharmacological Reviews $\mathbf{4 3}$ 109-142.

Rosman GJ, Martins TJ, Sonnenberg WK, Beavo JA, Ferguson K \& Loughney K 1997 Isolation and characterization of human cDNAs encoding a cGMP-stimulated $3^{\prime}, 5^{\prime}$-cyclic nucleotide phosphodiesterase. Gene 191 89-95.

Shimaoka M, Iida T, Ohara A, Taenaka N, Mashimo T, Honda T \& Yoshiya I 1995 NOC, a nitric-oxide-releasing compound, induces dose dependent apoptosis in macrophages. Biochemical and Biophysical Research Communications 209 519-526.

Shukovski L \& Tsafriri A 1994 The involvement of nitric oxide in the ovulatory process in the rat. Endocrinology 135 2287-2290.

Snyder GD, Holmes RW, Bates JN \& Van Voorhis BJ 1996 Nitric oxide inhibits aromatase activity: mechanisms of action. Journal of Steroid Biochemistry and Molecular Biology 58 63-69.

Stamler JS 1994 Redox signaling: nitrosylation and related target interactions of nitric oxide. Cell 78 931-936.

Van Voorhis BJ, Dunn MS, Snyder GD \& Weiner CP 1994 Nitric oxide: an autocrine regulator of human granulosa-luteal cell steroidogenesis. Endocrinology 135 1799-1806.

Van Voorhis BJ, Moore K, Strijbos P, Nelson S, Baylis SA, Grzybicki D \& Weiner CP 1995 Expression and localization of inducible and endothelial nitric oxide synthase in the rat ovary. Journal of Clinical Investigation 96 2719-2726.

Yamauchi J, Miyazaki T, Iwasaki S, Kishi I, Kuroshima M, Tei C \& Yoshimura Y 1997 Effects of nitric oxide on ovulation and ovarian steroidogenesis and prostaglandin production in the rabbit. Endocrinology 138 3630-3637.

Received 31 August 2000 Accepted 18 October 2000 